\title{
The penetrative offence in section 4 of the Sexual Offences Act 2003: Offenders, victims, and outcomes after detection
}

Dr Siobhan Weare

\begin{abstract}
Extensive research exists in relation to the Sexual Offences Act 2003, in particular rape and assault by penetration, the two most serious offences involving non-consensual sexual penetration of the victim. However, the other penetrative offence, causing a person to engage in (penetrative) sexual activity without consent, found in section 4 of the Act, has, to date, been excluded from national statistics and research. This article analyses novel data relating to the section 4 penetrative offence, collected using freedom of information requests, from 37 police forces in England and Wales over a 13-year period. The data explores victim and offender demographics and outcomes after detection. The findings challenge understandings around who the victims and perpetrators of penetrative sexual offences are.
\end{abstract}

\section{Keywords}

Sexual Offences Act 2003 section 4, female perpetrators, male victims, young offenders, case outcomes, gender

\section{Introduction}

The main sources of quantitative data relating to sexual offences in England and Wales are the Crime Survey for England and Wales (CSEW) (Kantar Public and Office for National Statistics n.d.) and police recorded crime data, which is frequently reported in government crime bulletins (e.g. Office for National Statistics 2019: Table A4). Both sources of data have allowed 
an increasingly detailed national picture to be painted in relation to victims, as well as perpetrators, of sexual violence. Alongside this, a substantial body of academic literature exists, incorporating both empirical data and theoretical perspectives, that considers the prevalence of sexual violence, as well as victims and offenders (e.g. Abdullah-Khan 2008; Brownmiller 1975; Rumney 2008; Temkin 2002).

Within existing scholarship and national sources of data, the sexual offences of rape (Sexual Offences Act 2003. s.1) and assault by penetration (Sexual Offences Act 2003. s.2) are widely recognised as the most serious offences within the Sexual Offences Act 2003 (SOA 2003) (Home Office 2000: $9 \&$ 16) because they involve non-consensual penetration. However, the SOA 2003 contains another penetrative (and thus equally serious) offence that has, to date, been overlooked by data collectors and researchers. This offence is found in section 4 of the Act; causing a person to engage in sexual activity without consent. This section is somewhat of an anomaly in Part I of the Act because it incorporates two offences; one involving penetrative sexual activity (found in subsection 4), and the other, non-penetrative (discussed in more detail below).

Whilst being regarded as one of the most serious sexual offences (Home Office 2000: 31-32), the nationally reported crime data does not include recording rates for the penetrative offence, only the umbrella offence incorporating both penetrative and non-penetrative activity (e.g. Office for National Statistics 2019; Table A4; Ministry of Justice, Home Office, and Office for National Statistics 2013a: Table 3.2 (where the umbrella code 22A is used)). Since April 2015, the Crime Survey for England and Wales has collected information on 'causing sexual activity without consent' (Office for National Statistics 2018c), however following the trend noted above, any sort of detail specifically relating to this offending has not been made available. 
This section of the Act also does not feature within existing scholarship, except in passing (Weare 2018a; Weare 2018b). As a result, nothing is publicly known about reporting and recording rates specifically associated with the section 4(4) penetrative sexual offence, nor the demographics of victims and offenders.

This article therefore makes an original contribution to knowledge by sharing, and analysing, Freedom of Information (FOI) request data on the penetrative offence in section 4(4) SOA 2003. The Freedom of Information Act 2000 (FOIA) was used to make requests to the 43 police forces in England and Wales in relation to the section 4(4) penetrative offence, covering the period 2005/06 - 2017/18. Data was collected, and is reported, on offence recording rates, victim and offender demographics, and outcomes after detection. Whilst some of the data collected reflects existing understandings around sexual offences and offending as broadly conceived, novel insights and findings are also reported. These relate to the proportion of men as victims and of children and young people as offenders, as well as the impact of the victims' sex on the outcome after detection.

The Sexual Offences Act 2003, section 4 - causing a person to engage in sexual activity without consent

Section 4 is one of the more complicated provisions within the SOA 2003 because it creates two separate offences where the victim is aged 13 or over; one involving non-penetrative sexual activity, and the other involving penetrative activity ( $R$ v Courtie 1984). For completeness, section 4 is presented here in full:

(1) A person (A) commits an offence if-

(a) he intentionally causes another person (B) to engage in an activity, 
(b) the activity is sexual,

(c) B does not consent to engaging in the activity, and

(d) A does not reasonably believe that B consents.

(2) Whether a belief is reasonable is to be determined having regard to all the circumstances, including any steps A has taken to ascertain whether B consents.

(3) Sections 75 [evidential presumptions about consent] and 76 [conclusive presumptions about consent] apply to an offence under this section.

(4) A person guilty of an offence under this section, if the activity caused involved

(a) penetration of B's anus or vagina,

(b) penetration of B's mouth with a person's penis,

(c) penetration of a person's anus or vagina with a part of B's body or by B

with anything else, or

(d) penetration of a person's mouth with B's penis,

is liable, on conviction on indictment, to imprisonment for life.

(5) Unless subsection (4) applies, a person guilty of an offence under this section is liable-

(a) on summary conviction, to imprisonment for a term not exceeding 6 months or to a fine not exceeding the statutory maximum or both;

(b) on conviction on indictment, to imprisonment for a term not exceeding 10 years.

As can be seen from the above, 'the mode of trial and sentence varies depending on whether there is or is not penetration' (Crown Prosecution Service n.d.). Where penetrative activity is involved this is an indictable offence and carries a maximum sentence of life imprisonment. 
Whilst, as noted above, section 4 incorporates two offences, the focus of the FOI requests, and thus this article, relates to the penetrative offence specifically. This approach has been taken to address gaps both in the literature, and in understanding, in relation to all penetrative offences found in Part I SOA 2003. Indeed, as it currently stands, only data in relation to rape and assault by penetration - two of the three penetrative offences - has been made publicly available, through for example Office for National Statistics data (Ministry of Justice, Home Office, and Office for National Statistics 2013a). It is not clear why the section 4(4) penetrative offence has been excluded from public data sources, however it's exclusion is problematic because it prevents an accurate and detailed picture of the most serious sexual offending from being painted, including in relation to who the victims and offenders are. For example, the only way to incorporate data on cases where men are forced-to-penetrate women is by looking at section 4, because the current legal definition of rape excludes these cases with the requirement of nonconsensual penile penetration by the perpetrator, rather than the victim (thus women can only be accomplices, not principal offenders in the offence of rape) (Sexual Offences Act 2003. s.1(1)).

The exclusion of the section 4(4) penetrative offence data suggests that this penetrative offence is viewed as being less serious than the other penetrative offences of rape (Sexual Offences Act 2003, s.1) and assault by penetration (Sexual Offences Act 2003, s.2). However, the penetrative sexual activity covered by section 4(4) is both serious and substantial, and includes:

where a victim is forced to carry out a sexual act involving their own person, such as masturbation, [where they are forced to] engage in sexual activity with a third party, who may be willing or not, or [where they are forced to] engage in sexual activity with the offender, e.g. a woman forces a man to penetrate her (Crown Prosecution Service, n.d.). 
The severity of the offending in such cases cannot be underestimated, with the CPS stating that 'one of the purposes of [the section 4 penetrative] offence ... is to create a female equivalent of the offence of rape, which carries the same level of punishment for what amounts to the same type of offending behaviour' (Crown Prosecution Service). Thus, by excluding this section of the Act from existing research and public data sources, a serious sexual offence, and the associated victims and offenders, are being overlooked.

\section{Methodology}

The aim of this study was to gather data on the section 4(4) penetrative offence, with the intention of gaining insights into police recording rates of one of the most serious sexual offences, as well as demographic data around victims and offenders. In doing so, the study aimed to fill a gap in knowledge in relation to penetrative sexual offences in England and Wales, collecting much of the same police data for this penetrative offence as is currently publicly available for the other penetrative sexual offences of rape and assault by penetration. In order to gather this data, the FOIA was used to make FOI requests to the 43 police forces in England and Wales ${ }^{1}$ in relation to the penetrative offence under section 4(4) SOA 2003. ${ }^{2}$ As a method of data collection for understanding sexual offences under the SOA 2003 the use of FOI requests to the police is novel, with only two previous studies in the UK taking a similar methodological approach (Bows and Westmarland 2017; Kingston and Thomas 2014).

\footnotetext{
${ }^{1}$ Police forces in Scotland and Northern Ireland were not included in the FOI process because section 4 SOA 2003 only applies in England and Wales; Scotland and Northern Ireland have separate (albeit similar) offences. 2 The FOIA provides a general right of access to information held by public bodies (s.1), including the police. If the body holds the information requested they must disclose it (s.1(1)(b)), unless it falls within one of the exemptions in the Act. E.g. if accessing the requested information would exceed the cost limit (s.12), if the information is already readily accessible to the requestor (s.21), or if disclosing the information would risk national security (s.24).
} 
The FOI requests were submitted to police forces on $21^{\text {st }}$ May 2018 in writing electronically, via email, or by completing an online form on force websites. To maximise the clarity of the requests and to ensure continuity in the types of information provided by police forces, the Home Office offence codes that are used for the section 4(4) penetrative offence were included. These are; $22 / 2$ - causing a female person to engage in sexual activity without consent (penetration), and $22 / 3$ - causing a male person to engage in sexual activity without consent (penetration) (Home Office 2018: 38). The FOI request asked each force for the following data in relation to these offence codes, broken down by year, from 2005/06 to 2017/18:

(1) The number of recorded offences;

(2) The number of recorded offences broken down by sex, age, and ethnicity of offenders;

(3) The outcome after detection (method of detection) (e.g. charge/ summons, non-sanction detections etc), broken down by sex, age, and ethnicity of offenders;

(4) The number of offenders who were cautioned, broken down by sex, age, and ethnicity of offenders.

The parameters of the data requested were informed by police recorded data which is currently publicly available for the other penetrative sexual offences of rape and assault by penetration (Ministry of Justice, Home Office and Office for National Statistics 2013b: Chapter 3).

Once data was received from each force it was reviewed and inputted into an Excel spreadsheet. Correspondence with forces was also stored and where they had not provided all of the data requested (despite follow-up emails), notes were made of any excluded data. The data that was provided then underwent descriptive analysis e.g. frequency and range.

\section{Challenges}


The majority of forces did not provide any or all of the data requested within the statutory timelimit of 20 working days (Freedom of Information Act 2000. s.10(1)). Only five forces provided some or all of the data requested within this time, with a further nine asking for clarifications on the data being requested. Many forces needed multiple 'chasing emails' over several weeks reminding them of their obligations under the FOIA before data was provided. Several forces explained that the delay in responding was due to the large number of FOI requests they were dealing with.

On several occasions forces argued against providing some of the data requested based on the s.40 FOIA exemption (personal data / identifying an individual). They argued that providing data on offenders' sex, age, and ethnicity may make it possible to identify them, either solely from this information or combined with information that may be accessible by other means. Refusals on this ground were successfully challenged in the majority of cases by highlighting that other forces with similar or lower levels of reporting (where it would presumably be just as easy or easier to identify offenders) had provided the data requested. The ways in which the data could be presented were also negotiated to overcome refusals. For example, not providing a break-down of offenders' sex by year (as requested), but instead providing totals covering the time period that they held it for.

Despite these challenges and limitations, the use of the FOIA enabled access to data that was otherwise publicly unavailable, and, as will be seen, analysis of this data has provided novel insights into a previously un-researched penetrative sexual offence.

\section{Results}


The data incorporated in this article reflects that provided by the $37^{3}$ forces who responded before the $15^{\text {th }}$ November $2018 .{ }^{4}$ Only $16(43 \%)$ of the forces were able to provide data that covered all 13 years it was requested over $(2005 / 06$ - 2017/18). The number of years' data provided by other forces varied between three years (Northamptonshire Police and Dorset Police), and 12 years (Merseyside Police, Northumbria Police, Suffolk Constabulary, and Hampshire Police). The most common reasons for being unable to provide data from all 13 years' were; 1. that the sub-classification of data into the two offence codes had not taken place until a date within the time period (it previously only existed in the overriding offence code (22A)). 2. That the data recording systems had changed during the time period and accessing data from the old system(s) exceeded the time/cost allowance under the FOIA (Freedom of Information Act 2000. s.12 and 13).

Not all forces provided all of the data requested, for example, some did not provide information on the outcome after detection, whilst others did not provide it on offender demographics such as ethnicity, Therefore, when presenting the results here, reference is made to the number of forces who provided the data under discussion. It should also be noted that because of the multitude of ways that forces presented the data they provided, it is not possible to explore intersections within the data, for example between sex and age of offenders, or between sex of offenders and the outcome after detection. As such, when exploring offender demographics, each characteristic is reported on separately.

\footnotetext{
${ }^{3}$ Whilst technically 38 police forces provided data in response to the FOI request, Dyfed-Powys police do not sub classify crimes and so were unable to differentiate between offences coded as $22 / 2$ and $22 / 3$. Therefore whilst they provided data, it has been excluded here.

${ }^{4}$ This cut-off date was selected because this was the point at which all of the data that had been provided had been collated and analysed, and the data tables constructed. Two police forces (Warwickshire Police and Wiltshire Police) provided data after this date which have not been included in this article.
} 
Finally, in reporting, and discussing the data, specific comparisons are not made with data that is publicly available for the other penetrative offences of rape and assault by penetration. This is because direct comparisons are difficult to make where rape is a gendered offence with only men being recognised as principle offenders, whereas assault by penetration and the section 4(4) penetrative offence are gender neutral. However, where appropriate, comparisons are made between the findings presented here and general trends found in publicly available data and research on sexual offences more broadly.

\section{Number of recorded offences}

37 police forces provided data on the total number of recorded offences, broken down by year and offence code. In total, 1763 section 4(4) penetrative offences were recorded (see Table 1). Of this number, $58.9 \%$ of the offences were recorded under offence code $22 / 2$, denoting that the victims were women aged 13 or older. $41.1 \%$ of the victims were men (see Table 1 ).

[Insert Table 1 here]

The police force that recorded the highest total number of section 4(4) penetrative offences was the Metropolitan Police, with a total of 307 offences recorded. The Metropolitan Police was also the force that recorded the highest number of offences involving a male victim (182). West Yorkshire Police recorded the highest number of offences involving a female victim (137).

\section{$\underline{\text { Offender demographics }}$}

Data in relation to offenders' sex, age, and ethnicity was requested and collected. In reporting this data it should be noted that it relates to offenders rather than offences (as seen in Table 1 above when reporting recorded offences). It should also be noted that the total number of 
offenders does not correspond with the total number of recorded offences for a number of reasons; 1 . Some offences were undetected or it was not possible to identify the offender(s) (see Table 6). 2. Some offenders committed multiple offences, or conversely, some offences were committed by multiple offenders. 3. Some police forces did not provide all of the offender demographic data requested. In reporting the offender demographic data, it is broken down into sex, age, and ethnicity, with each considered separately.

$\operatorname{Sex}$

33 police forces provided data on the sex of offenders. Men were most frequently recorded as offenders, regardless of the sex of the victim (see Table 2). Whilst men represented $93.4 \%$ of offenders in cases where the victim was a woman, they represented a much smaller proportion (60.1\%), where the victim was a man. In contrast, women only made up $6.6 \%$ of the offenders in cases involving female victims, but represented $39.9 \%$ of the offenders in cases involving male victims. Thus, whilst this data shows that women infrequently offended against other women, they made up a substantial proportion of the offenders in cases where men were victimised (see Table 2).

[Insert Table 2]

Only 12 forces recorded cases where both the offender and victim was female, with the highest number of female offenders in this context being recorded by Lincolnshire Police (7). Kent Police recorded the highest number of male offenders in cases involving female victims (93), followed by Lincolnshire Police (62). Kent Police also recorded the highest number of female offenders (24) and male offenders (40) in cases where the victim was male. 
25 police forces provided data on the ages of recorded offenders, broken down by offence code. The data was provided in a variety of formats. For example, some provided specific ages for offenders (e.g. 29, 43, 15), others provided frequency data for grouped age ranges, with forces often grouping age ranges differently (e.g. some forces grouped ages by decades, others grouped all those aged 21 or older together, with no further breakdown provided). Therefore, analysing and presenting this data was more challenging. Two tables using different age groupings (Tables 3 and 4 below) have been used to ensure that all of the data provided in response to the FOI requests is represented.

Table 3 incorporates the data provided broken into two age groups (10-20 years, and $21+$ years), as well as an additional category, 'ungrouped'. This 'ungrouped' data is that which cannot be put into either of the age groups because forces have categorised it differently, e.g. aged " $16+$ ", or "18-30". Table 4 then incorporates age data that could be grouped by decade, e.g. 20-29, to provide a more detailed overview of offenders' ages. The 'ungrouped' data represents a higher proportion here because of difficulties with converting all of the police data into these age groupings. It should be noted here that the further breakdown of data in Table 4 of the age group 10-19 years, into two sub-groups; $10-15$ and 16-19, has been done to highlight the number of offenders recorded as being under the legal age of sexual consent (16 years old) in England and Wales (Sexual Offences Act 2003. s.9).

[Insert Tables 3 and 4 here]

Both tables demonstrate that whilst offenders were most frequently recorded as being aged 21 or older in section 4(4) penetrative cases, a large proportion of the perpetrators were 
adolescents or children. This is something that is considered further in the discussion section below.

Kent Police recorded the highest total number of offenders in the 10-20 age range (66), as well as the highest number of offenders in this age range for both offence classifications (48 in cases involving female victims and 18 where they involved male victims). They also recorded the highest number of offenders aged 21 or older (44 in cases involving female victims, 21 in cases involving male victims, 65 offenders total).

\section{Ethnicity}

24 police forces provided data on offenders' ethnicity broken down into the two offence codes. 20 different ethnic categories were provided in the data received, with some only being used by one or two forces. For ease of understanding and presentation, these 20 categories have been reduced into four broad ones (see Table 5 below). In doing so, it is recognised that these four categories are not fully representative of the ethnic identities of offenders, but rather they provide an overview.

The vast majority of offenders $(88.9 \%)$ were recorded as being White. Indeed, 13 police forces (54.2\% of the forces who provided this data) recorded only white offenders. Whilst BAME offenders were recorded as perpetrators in a minority of cases, they were more frequently recorded as being involved in cases where the victim was a woman $(13.6 \%)$, than where they were a man $(6.8 \%)$.

[Insert Table 5 here] 


\section{$\underline{\text { Outcome after detection }}$}

34 police forces provided data on the outcome after detection, broken down by offence code. Three forces (Essex, Leicestershire, and Surrey Police) only provided data for cases where the offender was charged or summonsed, and one police force (Lancashire Constabulary) only provided data on the number of cautions broken down by offence code. Whilst this data has been included, it should be noted that these forces do not seem to have provided all of the data relevant to the outcome after detection, which may have some impact on the frequencies recorded in Table 6. Over 30 different outcomes were reported across the forces, with some again only being used by one or two forces.

Taking the same approach as with the ethnicity data above, and for ease of displaying and understanding this data, similar categories have been merged together. For example, all those relating to the victim withdrawing support are grouped under 'victim withdraws support'. This approach has resulted in a reduced number of 19 categories being included in Table 6 .

[Insert Table 6 here]

Four police forces reported no cases involving a charge or summons where the victim was female. This increased to 12 forces in cases where the victim was a male. Four forces Gloucestershire Constabulary, Gwent Police, Lincolnshire Constabulary, and Suffolk Constabulary - did not record charges or summonses in any of the section 4(4) penetrative offences they reported on. The Metropolitan Police had the highest total number of cases resulting in a charge/ summons, as well as the highest number where victims were male and female respectively. 
Many of the outcomes occurred at similar rates regardless of the sex of the victim. For example, cases involving a charge or summons occurred in approximately $14 \%$ of all cases (see Table 6). Similarly, the frequency with which no further action was recorded as the outcome was around $1.9 \%$ in cases involving male and female victims (Table 6). However, in some instances there were more substantial differences in the rates at which outcomes occurred depending on the sex of the victim. This is considered further below.

\section{Discussion}

Several aspects of the data presented here reflects existing understandings around sexual violence as broadly conceived. That is, more offences were recorded as being perpetrated against women than men (see Table 1), reflecting the existing evidence that shows that women constitute a larger proportion of victims of sexual violence than men. Indeed, the Crime Survey for England and Wales estimates that ' $20 \%$ of women and $4 \%$ of men have experienced some type of sexual assault since the age of 16' (Office for National Statistics 2018a). Thus, the higher number of offences recorded against female victims here are unsurprising.

The data presented here also shares similarities with what is understood in relation to the demographics of offenders. It is understood that the majority of perpetrators of sexual violence are men, regardless of the victims' sex (Ministry of Justice, Home Office, and Office for National Statistics 2013b). The data collected as a result of the FOI requests broadly mirrors this, albeit with some interesting findings in relation to the rate at which women are recorded as perpetrators, particularly against male victims (discussed in more detail below). Moreover, the finding that the majority of offenders were white reflects existing national data that shows that few offenders are from black or other ethnic minority backgrounds (Ministry of Justice, Home Office, and Office for National Statistics 2013b). Finally, the increasing number of 
section 4(4) penetrative offences recorded annually (see Table 1) mirrors increasing recording rates for sexual offences more broadly. Indeed, as seen in Table 1, since 2013/14 the number of offences recorded for both section 4(4) offence codes has consistently increased, a trend also seen for other sexual offences.

In Table 1 it can be seen that the number of forces who reported data over the time period also increased, suggesting perhaps part of the observed increase is due to increasing numbers of forces providing data. However, the peak in the number of forces reporting the data $(2015 / 16$ and 2016/17) does not directly correlate with the peak in the number of offences recorded (2017/18). Therefore, it is likely that other factors are at play in relation to increased recording rates, one of which could be the extensive media coverage given to sexual offending over the time period 2013-2018. For example; Operation Yewtree, the police operation investigating historical allegations of sexual abuse by, most notably, Jimmy Saville; the \#MeToo movement; and the football child sexual abuse scandals which emerged in November 2016, the most highprofile of which involved former Crewe Alexandra coach Barry Bennell. Moreover, in November 2014, Her Majesty's Inspectorate of Constabulary and Fire and Rescue Services' (HMICFRS) report on Crime Recording found that levels of police non-recording of sexual offences were particularly pronounced, resulting in forces making improvements to their recording practices (HMIC 2014: 19). Therefore, it is likely that 'improvements in recording practices and a greater willingness of victims to come forward to report such crimes, including non-recent victims' (Office for National Statistics 2018a) are the most likely explanations for the increase in recorded crime numbers over this period, both for the section 4(4) penetrative offence, as well as sexual offences more generally. 
Alongside similarities found in this data to broader understandings of sexual violence, there are a number of notable findings that warrant further discussion. These are; the high number of male victims, and in particular female perpetrator-male victim cases recorded, the issue of children and young people perpetrating this form of sexual violence, and whether certain outcomes after detection are more likely to occur depending on the sex of the victim. These will each be discussed in turn.

\section{$\underline{\text { Male Victims }}$}

Men were recorded as victims in $41.1 \%$ of the section $4(4)$ penetrative offences recorded by the police (see Table 1). This is a substantially higher proportion of male victims when compared with other sexual offences. For example, over the same time period, 05/06 - 17/18, in police recorded cases of rape where the victim was 16 or older, men only represented $5.2 \%$ of the victims (Office for National Statistics 2019: Table A4). Similarly, looking at sexual assaults where the victim was 13 or over, men made up $9.8 \%$ of the victims (Office for National Statistics 2019: Table A4). Comparing these statistics to those on the section 4(4) penetrative offence, it can be seen that men are recorded as victims in section 4(4) penetrative offence cases over four times more frequently.

Based on the data provided in response to the FOI requests it is difficult to determine why men make up a larger proportion of victims here compared to other sexual offences. However, one explanation could be that this offence incorporates forced to penetrate cases, where a man is forced-to-penetrate a woman's vagina, anus, or mouth, with his penis, and without his consent (Weare 2018a). As noted by the CPS, this is the 'female equivalent of the offence of rape' (Crown Prosecution Service n.d.). This type of offending behaviour is criminalised under section 4(4), whereas the same sort of behaviour, i.e. non-consensual (penile) sex, is 
criminalised in cases where men are the perpetrators (regardless of the sex of the victim) under the section 1 offence of rape. Therefore, the fact that a particular aspect of the offending behaviour captured by the section 4(4) penetrative offence applies specifically to male victims may offer some explanation for the higher recording rate. This suggestion is perhaps further supported by the fact that women were recorded as offenders in $39.9 \%$ of the cases involving male victims (see Table 2).

Another explanation for the higher recording rate of male victims under the section 4(4) penetrative offence could relate to a larger increase in reporting and recording when compared to female victims of the same offence. Indeed, cases involving female victims recorded between $2013 / 14-2017 / 18$ increased by $46.1 \%$. Over the same period, the number of cases involving male victims increased by $66.3 \%$. Moreover, as can be seen in Table 1 , there is a narrowing of the gender gap in relation to victimisation, to the extent that in 2017/18 more offences were recorded against male victims than females.

Regardless of the explanation(s) offered for the higher frequency with which men are recorded as victims of the section 4(4) penetrative offence, this finding is important in and of itself in dispelling myths that men are not victims of sexual violence, and that even when they are it is not 'serious' sexual violence that they experience (e.g. Struckman-Johnson 1988). Indeed, the fact that men made up over $40 \%$ of recorded victims of the section 4(4) penetrative offence, which is one of the most serious sexual offences found in the SOA 2003, provides compelling evidence to undermine these myths. That $39.9 \%$ of the offenders recorded in cases involving male victims were women is also important, as it directly contradicts the pervasive stereotype that men cannot be victims of sexual violence perpetrated by women (e.g. Weare 2018a; Struckman-Johnson 1988). 
The fact that cases involving a female perpetrator and a male victim made up such a substantial proportion of the total number of offences recorded against male victims also presents a challenge to myths around masculinity and male (hetero)sexuality. Namely, the 'lucky boy' syndrome that purports that all (heterosexual) men enjoy all sexual activity with all women all of the time (Struckman-Johnson and Struckman-Johnson 1994: 113) and 'the traditional view of masculinity, which dictates that men should be strong [and] assertive' (Davies 2002: 204) and thus able to prevent their victimisation at the hands of a 'weaker' female. Moreover, the fact that men reported these cases involving female perpetrators to the police suggests that they viewed them as non-consensual, as well as overwhelmingly negative and harmful, contradicting societal perceptions "that men do not experience trauma or stress [especially] at the hands of. . . a woman" (Oswald and Holmgreen 2013: 87). Thus it is clear that the findings presented here directly contradict multiple stereotypes around masculinity and male sexuality that are often used to deny, undermine, or minimise men's experiences of sexual violence.

\section{Children and young people as offenders}

The term children is used here to describe those aged 10-15 years old in Table 4 (i.e. under the legal age of sexual consent), and the term young people is used to describe those aged 16-19 in Table 4. Based on these categorisations, in Table 3 the larger age grouping of those aged 1020 comprises both children (10-15 years old) and young people (16-20 years old).

Depending on the way the data was grouped and included within Tables 3 and 4, children and young people either made up a substantial minority or a majority of offenders. In Table 3, $42.1 \%$ of the offenders (excluding the ungrouped category) were aged 10-20 years old, whereas in Table 4 this increased to $56.8 \%$ of offenders aged $10-19$ years old. In Table 4 , it can also be 
seen that $20 \%$ of the offenders were recorded as being children, i.e. under the legal age of sexual consent themselves. More specifically, children and young people comprised a higher proportion of offenders in cases where the victim was a female $(49.1 \%$ of cases in Table 3 (excluding the ungrouped category), and $62.1 \%$ of cases in Table 4), as compared to where they were male $(28.2 \%$ of cases in Table 3 , and $43.3 \%$ in Table 4$)$. This is further emphasised by the fact that five police forces recorded more offenders aged 10-20 than $21+$ in cases involving a female victim, whereas only one force (Dorset Police) recorded the same in relation to cases involving a male victim.

Whilst the issue of children and young people as perpetrators of sexual violence has been increasingly discussed within the media (e.g. Greenfield 2018; Heald 2016), research (e.g. Hackett et al. 2013), practice (NSPCC n.d.), and policy-making (House of Commons 2016) in recent years, 'acknowledgment of [the issue] is [still] relatively recent' (Vizard, Monck, and Misch 1995: 731) and thus is a 'relatively new area of work' (Vizard, Monck, and Misch 1995: 731). Moreover, much of the existing work in the area looks at children perpetrating against other children of all ages, something which is only partially relevant to the data presented here, which looks at section 4(4) penetrative offences committed against victims aged 13 or over, and could therefore include adult victims. Consequently, the amount of existing data pertaining to child and adolescent sexual offenders is somewhat limited. Nevertheless, the rates at which children and young people are recorded as offenders of the section 4(4) penetrative offence here are typically slightly higher than recorded for sexual offences more broadly, as well as within existing research in the area. For example, in research studies, it has been noted 'that prevalence of sexually abusive behaviour by children and young people is between $20-50 \%$ of all child sexual abuse' (Vizard 2014: 3). Moreover, in the Crime Survey for England and Wales (year ending March 2017), only $20 \%$ of the offenders in rape or assault by penetration cases 
(including attempts) were reported as being 19 years old or younger (Office for National Statistics 2018b: Table 13).

It is difficult to offer explanations for the higher proportion of children and young people recorded as offenders in section 4(4) penetrative offences due to the small amount of research done in this area. However, it is possible that one explanation is simply that the particular type of sexual activity criminalised under this offence is more frequently perpetrated by young people when compared to other sexual offences. For example, the offence covers instances where the perpetrator forces the victim to have penetrative sex with a third party. Research has clearly documented that this sort of activity regularly occurs in gangs, with 'girls and young women being used to sleep with boys as young as 10 to initiate them into gang life' (Centre for Social Justice: 16). Regardless of the explanation offered, these findings are worthy of further investigation in order to develop a clearer understanding of the contexts within which this offending takes place when children and young people are the offenders.

\section{$\underline{\text { Outcomes after detection }}$}

As noted above, many of the outcomes occurred at similar rates regardless of the sex of the victim (see Table 6). This included the percentage of cases which resulted in a charge or summons, which sat at around $14 \%$ in cases involving victims of both sexes. This detection rate is lower than typically found in sexual offences cases more broadly, where a charging/summonsing outcome occurs in approximately $25 \%$ of cases (Ministry of Justice, Home Office, and Office for National Statistics 2013a: Table 3.4). No explanation for this lower detection rate in section 4(4) penetrative offences emerges from the data. However it is possible to speculate that it may be at least partly attributable to the demographic differences found in relation to offenders and victims in these cases (discussed above). Moreover, these 
cases may present additional evidential difficulties which may make a charging decision less likely. For example, in forced-to-penetrate cases the male victim must have sustained an erection in order for the penetrative sexual activity to have occurred, and therefore proving a lack of consent on his behalf may be viewed as too substantial of an evidential difficulty to charge the offender.

For some outcomes after detection there were substantial differences between cases involving female victims and those involving male victims (see Table 6). Cases involving female victims were more likely to result in the offender being cautioned, when compared to cases involving male victims (in $2.7 \%$ of cases vs $1 \%$ ), and female victims more frequently withdrew their support for police action (16.4\% vs $10.8 \%)$. The police and CPS more frequently made the decision that it was not in the public interest to proceed with the case where the victim was female (in $5.7 \%$ of cases vs $1 \%$ ). The frequency with which offenders were undetected was also considerably higher in cases involving female victims $(14.4 \%$, vs $5.2 \%$ where the victim was male). On the other hand, evidential difficulties were reported more frequently in cases involving male victims (in $22 \%$ of cases, vs $13.5 \%$ ). A much larger proportion of the cases involving male victims had no outcome assigned / a none outcome $(34.3 \%)$, than where the victim was a female $(15.1 \%)$. It is difficult to speculate without further information why these differences have emerged, not least because of the complexity of police investigations into sexual offences, and the multitude of different factors that impact case outcomes. However, from the data presented here, it appears that the sex of the victim has a degree of impact on case outcomes involving the section 4(4) penetrative offence. This is something that would benefit from further research.

\section{Conclusion}


This article represents the first research conducted into the penetrative offence found in section 4(4) SOA 2003. Using the FOIA to gather the police data analysed is a relatively novel research method, with only two other studies in the UK on the SOA 2003 (Bows and Westmarland 2017; Kingston and Thomas 2014) taking such an approach. The FOIA allowed access to data that was previously publicly unavailable and provided important insights into the section 4(4) penetrative offence. Whilst analysis of the data resulted in some findings that are broadly in line with what is already understood about sexual offences, offenders, and victims, several findings are novel and present challenges to existing discourses. The most significant of these relate to who victims and offenders are, with a substantial (and increasing) number of male victims being recorded, and high levels of children and young people being recorded as offenders. Data analysis has also indicated that the sex of the victim may impact upon the outcome after detection in certain circumstances. Whilst speculative explanations for these findings are included within the analysis, future research would benefit from exploring underpinning reasons in more detail, so for example, why men make up such a substantial proportion of the victims of this offence.

It is clear that these novel findings challenge traditional understandings about gender and power in relation to both the perpetrators and victims of sexual violence. In doing so, they should not be viewed as detracting from data presented both in this article and elsewhere that demonstrate that women make up the majority of recorded victims of sexual violence, and men the majority of offenders. Rather these findings have the potential to expand discussions around sexual violence by considering different gendered paradigms around victims and perpetrators, as well as providing opportunities to critically interrogate the complex dimensions of power which underpin sexual violence. 
As noted at the beginning of the article, the section 4(4) penetrative offence is one of the most serious sexual offences within the Sexual Offences Act 2003. The failure to date to make data in relation to this offence publicly available has implications for victims, who may feel that this offence is viewed less seriously than other sexual offences. Victims are also unable to get a sense of the frequency with which this offence occurs, potentially leaving them feeling even more isolated and as if they, and their experiences, are an anomaly. It is therefore essential that going forwards, data on this offence is made publicly available in the same way that it is for the other two penetrative sexual offences of rape and assault by penetration.

Whilst the FOIA was a useful tool to gain access to the police crime recording data that this article is based upon, there were challenges associated with its use, which have been noted. These challenges demonstrate the limitations associated with the use of this method of data collection within research, in particular the way in which 'FOI teams [act] as gatekeepers to the data being requested' (Bows 2017: 38), and 'the inconsistency in the way information is released under FOI requests' (Bows 2017: 38). A further challenge that was revealed, specifically in relation to making FOI requests to police forces, is the volume of requests that they need to process.

There are also limitations associated with the use of police recorded crime data itself. These include under-recording of crime, particularly sexual offences (House of Commons 2014), 'inconsistencies in police recording practices' (Kingston, Elliott, and Thomas 2018: 10), and the decentralisation of policing which means a lack of consistency in the recording systems used by different forces (Bows and Westmarland 2017: 6). Moreover, police data is limited to recorded offences only, and therefore does not represent the true rate of offending, particularly in relation to sexual offences, where it is estimated that only $15 \%$ of sexual offences are 
reported to the police (Ministry of Justice, Home Office, and Office for National Statistics 2013b). These limitations mean that whilst the police recorded data used in this article provides important and original insights into the section 4(4) penetrative offence, additional research would be beneficial to develop further understandings in this area. This may take the form of gathering qualitative data, as well as additional quantitative data on, for example, the demographics of victims, the contexts in which these offences are perpetrated, and the relationships between victims and offenders. 


\section{References}

Abdullah-Khan, N. (2008), Male Rape: The Emergence of a Social and Legal Issue. Hampshire: Palgrave MacMillan.

Bows, H., (2017), 'Researching Sexual Violence Against Older People: Reflecting on the use of Freedom of Information Requests in a feminist study’ Feminist Review, 115: 30-45.

Bows, H., and Westmarland, N. (2017), 'Rape of Older People in the United Kingdom: Challenging the "Real-Rape" Stereotype' British Journal of Criminology, 57: 1-17.

Brownmiller, S. (1975), Against Our Will: Men, Women, and Rape. New York: Bantam Books.

Button, M., Blackbourn, D., and Tunley, M. (2014), 'The Not So Thin Blue Line After All?' Investigative Resources Dedicated to Fighting Fraud/ Economic Crime in the United Kingdom' Policing, 9(2): 129-142.

Centre for Social Justice. (2014), Girls and Gangs. Available at: https://www.centreforsocialjustice.org.uk/core/wp-content/uploads/2016/08/Girls-and-GangsFINAL-VERSION.pdf (Accessed: $27^{\text {th }}$ February 2019).

Crown Prosecution Service. (no date), Rape and Sexual Offences - Chapter 2 Sexual Offences Act 2003 - Legal Guidance. Available at: https://www.cps.gov.uk/legal-guidance/rape-andsexual-offences-chapter-2-sexual-offences-act-2003-principal-offences-and (Accessed: $27^{\text {th }}$ February 2019). 
Davies, M. (2002), 'Male sexual assault victims: a selective review of the literature and implications for support services' Aggression and Violent Behavior, 7: 203-214.

Freedom of Information Act 2000. (c. 36). London: HMSO.

Greenfield, P. (2018), Parents of girl, six, who was sexually abused by fellow pupils given payout. The Guardian. Available at: https://www.theguardian.com/uknews/2018/nov/21/parents-of-schoolchild-sexually-abused-by-fellow-pupils-given-payout (Accessed: 27 $7^{\text {th }}$ February 2019).

Hackett, S., Phillips, J., Masson, H., Balfe, M. (2013), 'Individual, Family and Abuse Characteristics of 700 British Child and Adolescent Sexual Abusers' Child Abuse Review, 22(4): $232-245$.

Heald, C. (2016), How do you treat very young sexual offenders? BBC News. Available at: https://www.bbc.co.uk/news/uk-37701618 (Accessed: 27 ${ }^{\text {th }}$ February 2019).

HMIC. (2014), Crime-recording: making the victim count. [pdf] London: HMIC. Available at: https://www.justiceinspectorates.gov.uk/hmicfrs/wp-content/uploads/crime-recordingmaking-the-victim-count.pdf(Accessed: $27^{\text {th }}$ February 2019).

Home Office. (2000), Setting the Boundaries: Reforming the Law on Sex Offences, Volume 1. [pdf] London: Home Office. Available http://webarchive.nationalarchives.gov.uk/+/http://:/www.homeoffice.gov.uk/documents/ 
vol1main.pdf? view=Binary $\left(\right.$ Accessed: $27^{\text {th }}$ February 2019).

Home Office (2018). Counting Rules for Recorded Crime - Sexual Offences [pdf] London: Home Office. Available at: https://assets.publishing.service.gov.uk/government/uploads/system/uploads/attachment data /file/694435/count-sexual-apr-2018.pdf (Accessed: 27 ${ }^{\text {th }}$ February 2019).

House of Commons, Public Administration Select Committee (2013-14), 2014. Caught RedHanded: Why we can't count on Police Recorded Crime Statistics. (HC 760, Thirteenth Report of Session 2013-14) - Report, together with formal minutes. London: HMSO.

House of Commons, Women and Equalities Committee (2016-17), 2016. Sexual harassment and sexual violence in schools. (HC 91, Third Report of Session 2016-17) - Report, together with formal minutes. London: HMSO.

Kantar Public and Office for National Statistics. (no date), Crime Survey for England and Wales. Available at: http://www.crimesurvey.co.uk/en/index.html (Accessed: 27th February 2019).

Kingston, S., Elliott, A., and Thomas, T., (2018) 'Cost calculations as a barrier to gaining information under the Freedom of Information Act 2000 from the police in England and Wales' Policing and Society, 29(7), 834-847.

Kingston, S., and Thomas, T. (2014) 'The police, sex work, and Section 14 of the Policing and Crime Act 2009’ The Howard Journal of Criminal Justice, 53(3): 255-269. 
Ministry of Justice, Home Office, and Office for National Statistics. (2013a), An Overview of Sexual Offending in England and Wales: Sexual Offending Overview Tables. Available at: https://www.gov.uk/government/statistics/an-overview-of-sexual-offending-in-england-andwales (Accessed: 27 $7^{\text {th }}$ February 2019).

Ministry of Justice, Home Office, and Office for National Statistics. (2013b), An Overview of Sexual Offending in England and Wales: Statistics Bulletin. [pdf] London: Ministry of Justice, Home Office, and Office for National Statistics. Available at: https://assets.publishing.service.gov.uk/government/uploads/system/uploads/attachment data /file/214970/sexual-offending-overview-jan-2013.pdf (Accessed: $27^{\text {th }}$ February 2019).

NSPCC. (no date), Harmful Sexual Behaviour. Available at: https://www.nspcc.org.uk/preventing-abuse/child-abuse-and-neglect/harmful-sexualbehaviour/ (Accessed: $27^{\text {th }}$ February 2019).

Office for National Statistics. (2018a), Sexual Offences in England and Wales: Year ending March $2017 . \quad$ Available at: https://www.ons.gov.uk/peoplepopulationandcommunity/crimeandjustice/articles/sexualoffen cesinenglandandwales/yearendingmarch2017 (Accessed: $27^{\text {th }}$ February 2019).

Office for National Statistics. (2018b), Sexual Offences in England and Wales: Year ending March $2017 \quad-\quad$ Appendix $\quad$ Tables. Available at: https://www.ons.gov.uk/peoplepopulationandcommunity/crimeandjustice/datasets/sexualoffe ncesappendixtables (Accessed: 27 $7^{\text {th }}$ February 2019). 
Office for National Statistics. (2018c), Sexual offending: victimization and the path through the criminal justice system. Available at: https://www.ons.gov.uk/peoplepopulationandcommunity/crimeandjustice/articles/sexualoffen dingvictimisationandthepaththroughthecriminaljusticesystem/2018-12-13 $\quad$ (Accessed: $27^{\text {th }}$ February 2019).

Office for National Statistics. (2019), Crime in England and Wales: Appendix Tables (Year ending June 2018). Available at: https://www.ons.gov.uk/peoplepopulationandcommunity/crimeandjustice/datasets/crimeinen glandandwalesappendixtables (Accessed: 27th February 2019).

Oswald, D., and Holmgreen, L. (2013), 'Female sexual aggression on college campuses: Prevalence, correlates, and perceptions' in B. Russell, ed., Perceptions of female offenders: How stereotypes and social norms affect criminal justice behaviours, 77-91, New York: Springer.

$R v$ Courtie [1984] AC 463

Rumney, P. (2008), 'Policing male rape and sexual assault' Journal of Criminal Law, 72(1): 67-86.

Sexual Offences Act 2003. (c.42). London: HMSO. 
Struckman-Johnson, C. (1988), 'Forced sex on dates: It happens to men too' Journal of Sex Research, 24: 234-241.

Struckman-Johnson, C., and Struckman-Johnson, D. (1994), 'Men pressured and forced into sexual experience' Archives of Sexual Behavior, 23: 93-114.

Temkin, J. (2002), Rape and the Legal Process. $2^{\text {nd }}$ ed. Oxford: Oxford University Press.

Vizard, E. (2014), Sexually harmful behaviours in children and young people with learning difficulties: Key points. DOI:10.13056/OP32.m.

Vizard, E., Monck, E., and Misch, P. (1995), 'Child and Adolescent Sex Abuse Perpetrators: A Review of the Research Literature' Journal of Child Psychology and Psychiatry, 36(5): 731756.

Weare, S. (2018a), 'From coercion to physical force: Aggressive strategies used by women against men in 'forced-to-penetrate' cases in the UK' Archives of Sexual Behavior, 47(8), 2191-2205.

Weare, S. (2018b), “I feel permanently traumatised by it': Physical and emotional impacts reported by men forced-to-penetrate women in the UK' Journal of Interpersonal Violence, 126, DOI: $10.1177 / 0886260518820815$. 


\section{Tables}

Table 1 - Total number of recorded offences, broken down by year and offence code, based on data provided by 37 police forces (2005/06 - 2017/18)

\begin{tabular}{|c|c|c|c|c|c|c|c|c|c|c|c|c|c|c|}
\hline Offence code & 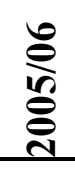 & 용 & 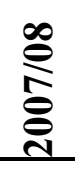 & 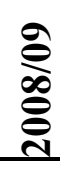 & 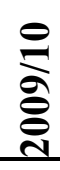 & 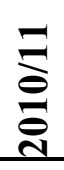 & 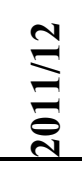 & 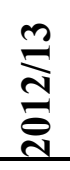 & 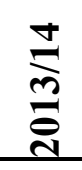 & 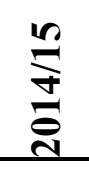 & $\frac{0}{\stackrel{0}{\pi}}$ & 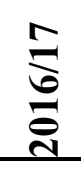 & 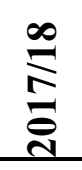 & $\begin{array}{l}\text { Total } \\
\text { N (\%) }\end{array}$ \\
\hline $\begin{array}{l}\text { Number of forces } \\
\text { who provided } \\
\text { data }\end{array}$ & 18 & 21 & 24 & 27 & 28 & 29 & 31 & 33 & 33 & 35 & 37 & 37 & 35 & N/A \\
\hline $\begin{array}{l}22 / 2-\text { female } \\
\text { victim }\end{array}$ & 54 & 39 & 39 & 36 & 29 & 47 & 69 & 48 & 80 & 109 & 171 & 152 & 166 & $\begin{array}{l}1039 \\
(58.9 \%)\end{array}$ \\
\hline $\begin{array}{l}22 / 3-\text { male } \\
\text { victim }\end{array}$ & 8 & 13 & 23 & 16 & 23 & 21 & 44 & 35 & 47 & 91 & 99 & 127 & 177 & $\begin{array}{l}724 \\
(41.1 \%)\end{array}$ \\
\hline Total & 62 & 52 & 62 & 52 & 52 & 68 & 113 & 83 & 127 & 200 & 270 & 279 & 343 & $\begin{array}{l}1763 \\
(100 \%)\end{array}$ \\
\hline
\end{tabular}

Table 2 - Sex of offenders, broken down by offence code, based on data provided by 33 police forces (2005/06 - 2017/18) (recorded offenders - frequency)

\begin{tabular}{|l|l|l|l|}
\hline Offence code & $\begin{array}{l}\text { Male } \\
\text { offender } \\
(\mathbf{N})\end{array}$ & $\begin{array}{l}\text { Female offender } \\
(\mathbf{N})\end{array}$ & $\begin{array}{l}\text { Total offenders } \\
(\mathbf{N})\end{array}$ \\
\hline $\mathbf{2 2 / 2}-$ female victims & 411 & 29 & 440 \\
\hline $\mathbf{2 2 / 3}-$ male victims & 155 & 103 & 258 \\
\hline Total across victims & 566 & 132 & 698 \\
\hline
\end{tabular}

Table 3 - Age of offenders, broken down by offence code, based on data provided by 25 police forces (2005/06 - 2017/18) (recorded offenders) (frequency)

\begin{tabular}{|l|l|l|l|l|}
\hline Offence Code & \multicolumn{3}{|l|}{ Age of offender (years) (N) } & Total (N) \\
\hline & $10-20$ & $21+$ & Ungrouped & \\
\hline $\mathbf{2 2 / 2}$ - female victim & 170 & 181 & 24 & 375 \\
\hline $\mathbf{2 2 / 3}-$ male victim & 51 & 130 & 5 & 186 \\
\hline Total across victims & 221 & 311 & 29 & 561 \\
\hline
\end{tabular}


Table 4 - Age of offenders, grouped by decade, broken down by offence code, based on data provided by 25 police forces (2005/06 - 2017/18) (recorded offenders) (frequency)

\begin{tabular}{|c|c|c|c|c|c|c|c|c|c|c|}
\hline \multirow{3}{*}{$\begin{array}{l}\text { Offence } \\
\text { code }\end{array}$} & \multicolumn{9}{|c|}{ Age of offender (years) (N) } & \multirow{2}{*}{$\begin{array}{l}\text { Total } \\
\text { (N) }\end{array}$} \\
\hline & \multicolumn{2}{|l|}{$10-19$} & \multirow[t]{2}{*}{$20-29$} & \multirow[t]{2}{*}{$\begin{array}{l}30- \\
39\end{array}$} & \multirow[t]{2}{*}{$\begin{array}{l}40- \\
49\end{array}$} & \multirow[t]{2}{*}{$\begin{array}{l}50- \\
59\end{array}$} & \multirow[t]{2}{*}{$\begin{array}{l}60- \\
69\end{array}$} & \multirow[t]{2}{*}{$\begin{array}{l}70- \\
79\end{array}$} & \multirow[t]{2}{*}{ Ungrouped } & \\
\hline & $10-15$ & $\begin{array}{l}16- \\
19\end{array}$ & & & & & & & & \\
\hline \multirow{2}{*}{$\begin{array}{l}22 / 2- \\
\text { female } \\
\text { victim }\end{array}$} & \multicolumn{2}{|l|}{151} & \multirow[t]{2}{*}{37} & \multirow[t]{2}{*}{29} & \multirow[t]{2}{*}{16} & \multirow[t]{2}{*}{6} & \multirow[t]{2}{*}{2} & \multirow[t]{2}{*}{2} & \multirow[t]{2}{*}{132} & \multirow[t]{2}{*}{375} \\
\hline & 59 & 92 & & & & & & & & \\
\hline \multirow{2}{*}{$\begin{array}{l}22 / 3- \\
\text { male } \\
\text { victim }\end{array}$} & \multicolumn{2}{|l|}{42} & \multirow[t]{2}{*}{19} & \multirow[t]{2}{*}{20} & \multirow[t]{2}{*}{10} & \multirow[t]{2}{*}{6} & \multirow[t]{2}{*}{0} & \multirow[t]{2}{*}{0} & \multirow[t]{2}{*}{89} & \multirow[t]{2}{*}{186} \\
\hline & 9 & 33 & & & & & & & & \\
\hline \multirow[t]{2}{*}{ Total } & \multicolumn{2}{|l|}{193} & \multirow[t]{2}{*}{56} & \multirow[t]{2}{*}{49} & \multirow[t]{2}{*}{26} & \multirow[t]{2}{*}{12} & \multirow[t]{2}{*}{2} & \multirow[t]{2}{*}{2} & 221 & 561 \\
\hline & 68 & 125 & & & & & & & & \\
\hline
\end{tabular}

Table 5 - Ethnicity of offenders, broken down by offence code, based on data provided by 24 police forces (2005/06 - 2017/18) (recorded offenders) (frequency)

\begin{tabular}{|l|l|l|l|l|l|}
\hline Offence code & White (N) & $\begin{array}{l}\text { Asian } \\
(\mathbf{N})\end{array}$ & Black (N) & Mixed (N) & Total (N) \\
\hline $22 / 2-$ female victim & 216 & 13 & 18 & 3 & 250 \\
\hline $22 / 3-$ male victim & 138 & 5 & 4 & 1 & 148 \\
\hline Total & 354 & 18 & 22 & 4 & 398 \\
\hline
\end{tabular}

Table 6 - Outcome after detection, broken down by offence code, based on data provided by 34 police forces (2005/06 - 2017/18) (recorded offences - frequency)

\begin{tabular}{|c|c|c|c|}
\hline Outcome after detection & $\begin{array}{l}\text { 22/2 - female victim } \\
\text { N (\%) }\end{array}$ & $\begin{array}{l}22 / 3-\text { male victim } \\
\text { N (\%) }\end{array}$ & Total \\
\hline Cautioned (incl. youth) & $21(2.7 \%)$ & $5(1 \%)$ & 26 \\
\hline Charged/ summonsed & $111(14.4 \%)$ & $72(13.9 \%)$ & 183 \\
\hline Evidential difficulties & $104(13.5 \%)$ & $114(22 \%)$ & 218 \\
\hline Victim withdraws support & $126(16.4 \%)$ & $56(10.8 \%)$ & 182 \\
\hline $\begin{array}{l}\text { Not in public interested to proceed - } \\
\text { police/CPS }\end{array}$ & $44(5.7 \%)$ & $5(1 \%)$ & 49 \\
\hline
\end{tabular}




\begin{tabular}{|l|l|l|l|}
\hline Investigation complete & $21(2.7 \%)$ & $16(3.1 \%)$ & 37 \\
\hline Enquiries continue/ decision pending & $14(1.8 \%)$ & $14(2.7 \%)$ & 28 \\
\hline $\begin{array}{l}\text { Other agency/ body has investigatory } \\
\text { primacy }\end{array}$ & $6(0.8 \%)$ & $3(0.6 \%)$ & 9 \\
\hline Offender has died & $2(0.3 \%)$ & $2(0.4 \%)$ & 4 \\
\hline No outcome assigned/ none outcome & $116(15.1 \%)$ & $178(34.3 \%)$ & 294 \\
\hline Non-sanction detections & $5(0.7 \%)$ & $10(1.9 \%)$ & 15 \\
\hline Undetected & $111(14.4 \%)$ & $27(5.2 \%)$ & 138 \\
\hline Hist - resolved & $18(2.3 \%)$ & $5(1 \%)$ & 23 \\
\hline UU - unresolved & $13(1.7 \%)$ & $0(0 \%)$ & 13 \\
\hline No Further Action & $16(2.1 \%)$ & $9(1.7 \%)$ & 25 \\
\hline Action taken by another agency/body & $13(1.7 \%)$ & $0(0 \%)$ & 13 \\
\hline Insufficient other & $25(3.2 \%)$ & $0(0 \%)$ & 25 \\
\hline Charged - alternate offence & $4(0.5 \%)$ & $2(0.4 \%)$ & 6 \\
\hline Locate Trace & $0(0 \%)$ & $1(0.2 \%)$ & 1 \\
\hline Total & 770 & 519 & 1289 \\
\hline
\end{tabular}

